2. Teplov, B. (1947). Psychology of musical abilities. Moscow; Leningrad: APN RSFSR [in Russian].

3. Shenderovich, E. (1987). About overcoming pianistic difficulties in claviers: tips from the accompanist. Moscow: Music [in Russian].

4. Mikhailov, Oleksandr (2019). Unterricht per Skype als Alternative Lernmethode. Zbrich: Zbrcher Hochschule der Konste, Departement Musik [in German].

5. Backing track. URL: http://ru.m.wikipedia.org>wiki [in Russian].

6. History of the creation of Skype. URL: https://sites.google.com/ site/cerezskajpvkontakteidr/istoria-sozdania-skype [in Russian].

7. Backing track. www.as-workshop.ru [in Russian].

УДК $78.03+782+78.07$

DOI https://doi.org/10.31723/2524-0447-2020-30-2-26

\author{
Валентина Борисівна Васильєва \\ ORCID: 0000-0002-3883-0005 \\ народна артистка України, \\ в. о. професора кафедри сольного співу
}

Одеської національної музичної академії імені А. В. Нежданової pobeda-vik@ukr.net

\title{
ТЕХНІЧНІ РЕКОМЕНДАЦІЇ ЩОДО ВИКОНАННЯ РОЛІ МАТЕРІ В ОПЕРІ «КАТЕРИНА» М. АРКАСА ЗА ОДНОЙМЕННОЮ ПОЕМОЮ Т. Г. ШЕВЧЕНКА
}

Метою роботи є розгляд прикладів музичного втілення образу Матері, виявлення його стійких типологічних особливостей виконання й аналіз показової в иьому аспекті партії Матері в опері Миколи Аркаса «Катерина» за однойменною поемою Тараса Григоровича Шевченка у виконавському контексті. Методологія дослідження - суміщення принципів історико-культурологічного та типологічного методів, а також стильового аналізу виконання. Наукова новизна. У сучасних дослідженнях оперного мистецтва не достатньо висвітлено проблеми виконавської специфіки щодо музично-художнього втілення образу матері та розкриття ї̈ на основі найбільш показового об'єкта дослідження української (в європейському контексті) оперної музики XIX-XX $\mathrm{cm}$.

(C) Васильєва В. Б., 2020 
Тому виконавська інтерпретація специфічних питань втілення образу Матері в опері Миколи Аркаса «Катерина» за однойменною поемою Тараса Григоровича Шевченка суттєво доповнюе музикознавчу теорію оперного мистецтва та його виконавського аспекту. Висновки. Узагальнюючи розгляд материнського образу в контексті розвитку оперної музики XIX-XX cm., можна зробити такі висновки: тема материнства й образ Матері є однією з найбільш стійких сюжетних ліній в історії європейської культури в різних сферах художнього мистецтва. Архетипічність образу Матері зумовлюе його незмінні, стійкі риси - жертовність, красу, ідеальність, які зберігаються протягом історичного розвитку й у різноманітті творчого проявлення. Ці стійкі риси утворюють специфічні особливості художнього образу Матері. Саме з XIX cm. в оперній музиці можна говорити про образ Матері як самостійне явище, стійкий тип героїні, що несе ідею безумовної та жертовної Любові. Для української традиції характерне домінування материнства в образі героїні, яку представлено насамперед як матір, $i$ ие формує логіку розкриття ії образу. Зазначений твір є визнаним шедевром світового оперного мистецтва. Виконання партії Матері в опері «Катерина» вимагає від співачки великої напруги голосового апарату, великої насиченості, барвистості звуку, додаткової концентраціі енергії, виразної декламації в речитативах, поривності, темпераменту. Головною задачею виконавиці-вокалістки є повноцінне художнє втілення сценічного образу. Особливості створення сиенічного образу Матері та його інтерпретації розкриті на прикладі власного виконання автора cmammi.

Ключові слова: образ Матері, особливості виконання, музичне втілення, створення образу, національний символ.

Vasilyeva Valentyna Borysivna, People's Artist of Ukraine, Acting Professor at the Solo Singing Department of the Odessa National A. V. Nezhdanova Academy of Music

Technical recommendations for the role of Mother in the opera “Catherine” by N. Arkas on the eponymous poem T. G. Shevchenko

The purpose of the article is to consider examples of the musical embodiment of the image of the Mother, to identify its stable typological features of performance and analysis of the most significant in this aspect of the Mother's part in Nikolai Arkas' opera "Katerina" based on the poem of the same name by Taras Shevchenko in the performing context. The methodology of the article is a combination of the principles of historical, cultural and typological methods, as well as stylistic analysis of performance. The scientific novelty. In modern studies of operatic art, the problems of the performing specificity of the musical and artistic embodiment of the image of the mother and its disclosure on the basis of the most significant object of research - Ukrainian (in the European context) opera music of the 19th-20th centuries are not sufficiently illuminated. Therefore, the performing interpretation of specific issues, the embodiment of the Mother's image in Nikolai Arkas's opera "Katerina" based on the poem of the same name by Taras Grigorievich Shevchenko significantly 
complements the musicological theory of operatic art and its performance aspect. Conclusions. Summarizing the mother image in the context of the development of opera music of the nineteenth and twentieth centuries, we can draw the following conclusions: the theme of motherhood and the image of the mother is one of the most stable storylines in the history of European culture in various fields of artistic art. The archetypal nature of the mother's image determines his constant, enduring features - sacrifice, beauty, ideality, which persist throughout historical development and in the variety of creative expression. These persistent features form the specific features of the mother's artistic image. It is from the nineteenth century in opera music that one can claim the image of the Mother as an independent phenomenon, a steady type of heroine who carries the idea of unconditional and sacrificial Love. The Ukrainian tradition is characterized by the dominance of Motherhood in the image of the heroine, who is presented primarily as a Mother, and this forms the logic of the disclosure of her image. This work is a recognized masterpiece of world opera. The performance of the Mother's part in the opera "Katerina" requires from the singer great tension of the vocal apparatus, great saturation, brilliance of sound, additional concentration of energy, expressive declamation in recitative, bright temperament. The main task of the performer-vocalist is the full-fledged artistic embodiment of the stage image. The peculiarities of creating the stage image of the Mother and its interpretation are revealed on the example of the author's own performance.

Key words: Mother image, performance features, musical embodiment, image creation, national symbol.

Васильева Валентина Борисовна, народная артистка Украины, и. о. профессора кафедры сольного пения Одесской национальной музыкальной академии имени А. В. Неждановой

Технические рекомендации для исполнения роли Матери в опере «Катерина» Н. Аркаса по одноименной поэме Т. Г. Шевченко

Целью статьи является рассмотрение примеров музыкального воплощения образа Матери, выявление его устойчивых типологических особенностей исполнения и анализ показательной в данном аспекте партии Матери в опере Николая Аркаса «Катерина» по одноименной поэме Тараса Григорьевича Шевченко в исполнительском контексте. Методология статьи - совмещение принципов историко-культурологического и типологического методов, а также стилевого анализа исполнения. Научная новизна. В современных исследованиях оперного искусства недостаточно освещены проблемы исполнительской специфики музыкально-художественного воплощения образа матери и ее раскрытие на основе наиболее показательного объекта исследования украинской (в европейском контексте) оперной музыки XIX-XX вв. Поэтому исполнительская интерпретация специфических вопросов воплощение образа Матери в опере Николая Аркаса «Катерина» по одноименной поэме Тараса Григорьевича Шевченко существенно дополняет музыковедческую теорию оперного искусства и его исполнительного аспекта. Выводы. Обобщая рассмотрение материнского образа в 
контексте развития оперной музыки XIX-XX вв., можно сделать следуюшие выводы: тема материнства и образ Матери является одной из самых устойчивых сюжетных линий в истории европейского искусства в разных сферах художественного творчества. Архетипичность образа Матери обусловливает его неизменные, устойчивые черты - жертвенность, красоту, идеальность, которые сохраняются на протяжении исторического развития и в разнообразии творческих преломлений. Эти устойчивые черты образуют специфические особенности художественного образа Матери. Именно начиная с XIX в. в оперной музыке можно говорить об образе Матери как о самостоятельном явлении, устойчивом типе героини, несущем идею безусловной и жертвенной Любви. Для украинской традиции характерно доминирование именно Материнства в образе героини, которая представлена в первую очередь в качестве Матери, и это формирует логику раскрытия ее образа. Указанное произведение является признанным шедевром мирового оперного искусства. Исполнение партии Матери в опере «Катерина» требует от певицы большого напряжения голосового аппарата, большой насыщенности, красочности звука, дополнительной концентрации энергии, выразительной декламации в речитативах, яркого темперамента. Главной задачей исполнительницы-вокалистки является полноценное художественное воплощение сценического образа. Особенности создания сиенического образа Матери и его интерпретации раскрыты на примере собственного исполнения автора статьи.

Ключевые слова: образ Матери, особенности исполнения, музыкальное воплощение, создание образа, национальный символ.

Актуальність теми дослідження. Питання щодо музично-художніх принципів втілення теми й образу Матері в оперній музиці досі не було об'єктом спеціального дослідження. Виходячи з того, що образ Матері у європейській опері є малопомітним серед таких стійких типів і характерів, як героїня, субретка та ін., але, тим не менш, історично стабільно присутній в оперних сюжетах, уявляється актуальним розгляд його як особливого і типологічно стійкого явища. Виявлення характерних рис і особливостей функціонування образу Матері в оперній музиці як певного типу оперної героїні надає виконавиці можливості усвідомлення його як цілісного явища, а це багато в чому зумовлює логіку виконавської інтерпретації та принципи формування виконавської концепціï. Тому звернення до цієї теми допоможе хоч у малому ступені заповнити прогалини у сучасному вивченні українського оперного мистецтва.

Метою дослідження $є$ розгляд прикладів музичного втілення образу Матері, виявлення його стійких типологічних 
особливостей виконання й аналіз найбільш показової в цьому аспекті партії Матері в опері Миколи Аркаса «Катерина» за однойменною поемою Тараса Григоровича Шевченка у виконавському контексті.

Наукова новизна. У сучасних дослідженнях оперного мистецтва недостатньо висвітлено проблеми виконавської специфіки щодо музично-художнього втілення образу матері та розкриття іiі на основі найбільш показового об'єкта дослідження - української (в європейському контексті) оперної музики XIX-XX ст. Тому виконавська інтерпретація специфічних питань втілення образу Матері в опері Миколи Аркаса «Катерина» за однойменною поемою Тараса Григоровича Шевченка суттєво доповнює музикознавчу теорію оперного мистецтва та його виконавського аспекту.

Виклад основного матеріалу. Образ жінки-Матері займає особливе місце в поезії Тараса Григоровича Шевченка. Він зображує свій особистий ідеал жінки. Шевченківська жінка щира, лагідна, добра, чисте джерело любові та розуміння, часом вона є беззахисною жертвою, доля якої складається іноді трагічно. Цій темі поет присвятив декілька творів, у т. ч. поему «Катерина». До образу Матері у творі Тараса Григоровича Шевченка можна віднести як образ молодої дівчини 3 маленькою дитиною, так і образ Матері похилого віку, який $є$ більш наповненим і символічним. Більш того, образ Матері у творчості українського поета уособлює народну мудрість, народну мораль. «Не знаю у всесвітній літературі поета, писав Іван Франко, - який передав би так високо і так щиро ідеал жінки-матері» [9, с. 33].

У своєму творі Тарас Григорович Шевченко підніс образ жінки-матері на найвищий п’єдестал моральної краси та величі, які послужили джерелом втілення цієї теми в опері українського композитора Миколи Аркаса «Катерина».

Багато імен українських композиторів було забуто, ноти загублено. Така ж доля була й у Миколи Аркаса, одного 3 видатних діячів української культури другої половини XIX ст., автора опери «Катерина», яка користується успіхом і любов’ю слухачів. Ця опера $є$ прекрасним прикладом співочої мелодійності, щедрої задушевності, геніальної простоти.

Отже, ці переваги викликають живий інтерес у всі часи та на усіх майданчиках, де звучала ця опера. Саме Микола Аркас написав першу оперу на шевченківський сюжет. Недолік май- 
стерності не давав Миколі Аркасу можливості легко слідувати своїм фантазіям. Тому він обмежився вокальним жанром, основний акцент зробив на шевченківське слово, яке йшло із глибин душі. У листі театральному діячу та режисеру П. Саксаганському він пише: «Може, вона (опера «Катерина») не справить того сподівання, якого хотілося б, бо до твору великого нашого Тараса не моїй слабкій музиці брянчити, але осмілився і я свого додати, щоб пісня його ширилась між нашим людом, щоб бачили вони те, що тяжко і болісно накипало, на його серці і вилилось у стиху могутнім» [8, с. 50].

Партія Матері в опері «Катерина» написана композитором для мецо-сопрано. Перше знайомство з цим глибоким образом потрібно починати не 3 клавіру. Насамперед необхідно перечитати «Катерину» Тараса Григоровича Шевченка, зрозуміти та прийняти вищий рівень тогочасної моральності, який сьогодні здається непомірно жорстоким. Щоб зрозуміти побут та одяг того часу та щоб почуватися комфортно на сцені та в образі, необхідно вивчати досконально історію українського костюму та побуту, навчитися ходити в цьому костюмі та ін. Поступово почне вимальовуватися образ тогочасної жінки, вміння рухатися, жестикулювати, слухати та виголошувати слова та наголоси. Але це тільки загальний образ жінки, після цього треба все це приміряти на конкретний образ Матері працюючи з музичним матеріалом, відточувати фрази, виспівуючи дуже нелегку вокальну партію.

Музична тема образу Матері пронизана теплою лірикою, отже, можна сказати, що в деяких місцях наближається до українського міського романсу, але ми чуємо українські інтонаційні обороти. Оскільки образ Матері є спочатку драматичним, то і музика, відповідно, напружена.

У звучанні струнних інструментів ми чуємо драматичну тему: то явний відчай, то безкрайня, ще ніким не розгадана материнська любов, яка переходить у покірність. I цю дивну гаму почуттів співачці необхідно передати насамперед голосом, поглядом і жестом.

Робота над партією повинна складатися 3 відточування кожної фрази, з пошуку нових барв у голосі. Якщо прислухатися до драматургії, то звичайно зрозуміло, яку барву надати голосу: наситити голос грудним тембром або залишити світлим. Весь сенс репетицій у тому, щоб не просто співати красиво голі ноти - це ремесло, а щоб довести за час репетицій 
свій текст до такого стану, щоб співачка повірила, що слова, які вона промовляє, не слова Тараса Григоровича Шевченка, а іiі власні, і народжуються ці слова в цю мить.

I коли співак-актор добивається цього, він опиняється на вершині задоволення, тоді мова ллється природно, рухи теж природні, слухач все розуміє, співчуває і ніби залучається до цієї гри справжніх почуттів. Тоді не треба пояснювати глядачу, що опера - це елітарне мистецтво, і не кожен здатен іiї зрозуміти. Наша мета - захопити глядача красивим природним співом і справжнім життям на сцені. Глядач все зрозуміє й оцінить кропітку працю, тож співачка повинна змусити здригнутися і зазвучати найтонші та найглибші струни його душі.

Образ Матері традиційно притаманний українській літературі та поезії, тому його можна розглядати як особливе тематичне явище, що має глибинні культурні корені. Український образ Матері є національним культурним символом, який не втратив свого високого значення від древніх часів і дотепер. Якщо говорити про такі поняття, як «тема Матері» або «образ Матері», то визначається, що ми бачимо насамперед жінку-матір.

Материнство - саме цей аспект стає головним у будь-якому жіночому образі. Під материнством розуміємо не тільки сам факт народження дітей, але й захист їх упродовж усього життєвого шляху.

Часто Тарас Григорович Шевченко підіймає проблеми нелюдських умов існування жінок. Образ і характер - два ключові поняття при аналізі художнього твору, в т. ч. музичного. За допомогою образів художник немов повідомляє нам про своє розуміння життя. Образ зазвичай несе в собі деякий ідеальний сенс, у ньому втілюється суб'єктивні уявлення художника про світ навкруги нього та про людей у цьому світі. «Образ - серце мистецтва, а власне мистецтво - це спосіб мислення художніми образами» [9, с. 93]. Форма образу завжди «особиста, вона несе незгладимий слід авторської ідейності» [13, с. 131]. Ще Г.Ф. Гегель відзначив, що «змістом мистецтва є ідея, а його формою - плотське образне втілення» [5, с. 28]. В. Халізєєв говорить, що художні образи «утворюються за активної участі уявлення: вони не просто відтворюють одиничні факти, але й згущують, концентрують суттєві для автора сторони життя в ім'я iї оцінювального осмислення» [14, с. 144]. 
«Катерина» - це відгук справжнього патріота на потребу створення національної опери для народної сцени. При написанні лібрето опери «Катерина» Микола Аркас переробив твір, ввівши, зокрема, в дію молодого парубка Андрія, котрий уособлює в опері позитивне начало. Виник драматургічний трикутник Андрій - Катерина - Іван. Це призвело до того, що драма «Катерина» стала трактуватися в особистісному ключі, а зовсім не була наслідком тих соціальних суперечностей, які так глибоко розкриті в поемі Тараса Григоровича Шевченка.

Музика опери пронизана теплою лірикою. Музична мова наспівна і щира. У ряді сольних місць вона наближається до українського міського романсу, а в хорах - до української народної пісні. У цьому полягає іiї незаперечна цінність.

Вже увертюра викликає спогад про широкі степи із живописними селами, в одному з яких відбувається зображена в опері драма. Початок увертюри - напружена тема струнних інструментів, далі проводяться теми, що згодом прозвучать в опері як характеристики героїв. Велику увагу Микола Аркас приділяє хоровим епізодам. Це обробки старовинних веснянок «Ой в неділю» (жіночий хор, хор парубків), «Гей, по синьому морю». Хор «То лі не береза, то лі не кудрява» взагалі побудований на російській народній темі.

Говорячи про сольні номери, слід відзначити, що навіть у тих із них, які написані під впливом міського романсу, цілком виразно відчуваються українські інтонаційні звороти. До найяскравіших зразків цього роду слід віднести колискову Катерини із III дії.

У кінці XIX ст. складається поняття оперної майстерності, що органічно поєднує вокальні й акторські навички. Вимоги до виконавців - оркестру, хору, солістів - випливають з уявлень про оперний театр як про театр музично-драматичний.

Опера «Катерина» була написана Миколою Аркасом у 1891 р., але впродовж п'яти років рукопис пролежав у цензурних відомствах Москви та Києва. Лише у 1897 р. опера вийшла у світ на малій батьківщині Аркаса, у Миколаєві, за рахунок автора. На обкладинці видання стояло лише прізвище Тараса Шевченка, авторство музики і лібрето були приховані криптонімом «Н. А. ...๖», а зверху присвята: «Любій, незабутній жінці моїй Олесі». 
При створенні партитури Микола Аркас обробив і використав значну кількість із 400 українських народних пісень, які вони разом із дружиною Ольгою Іванівною збирали в різних місцях, відвідуючи села Миколаївщини та Полтавщини, а також почуті від кобзарів і бандуристів, котрих композитор запрошував у свій дім у Миколаєві. Текст лібрето написав сам. Нову літературну обробку лібрето здійснив у 1963 р. Діодор Бобир.

Партії головних героїв Микола Аркас наділив характерною для української пісенності виразною мелодійністю. Хорові сцени побудовано на народних мелодіях, що позначає їх особливим колоритом. Опера має деякі відмінності порівняно 3 поемою. В огляді спектаклів українських театрів, присвячених річницям до дня народження Тараса Шевченка, опера «Катерина» посіла перше місце.

Виконання партії Матері в опері «Катерина» Миколи Аркаса вимагає від співачки великої напруги голосового апарату, великої насиченості, барвистості звуку, особливо у верхньому регістрі, на якому лежить основне навантаження в кульмінаційних моментах. Виконання цієї партії вимагає додаткової концентрації енергії, виразної декламації в речитативах, поривності, темпераменту, іноді інструментального тембру в окресленні та забарвленні вокальної мови.

Головною задачею виконавця-вокаліста $є$ повноцінне художнє втілення сценічного образу. Щоб заспівати цю партію, замало вивчити музичний матеріал, знати все про образ, який будеш створювати. Треба оволодіти диханням, відчути струмування повітря, яке йде від діафрагми до голосниць. Також необхідно навчитися сполучати силу звуку, висоту тону з рухом діафрагми, знайти тільки тобі притаманну власну манеру виконання, у якій кожна проспівана фраза i жест будуть наслідком відчутої музики та з'єднувалися 6 із творчим задумом Миколи Аркаса.

Ритм - душа твору. У цій ролі не треба уповільнювати ритм і таким чином хизуватися голосом, бо це спотворить ідею образу Матері емоційно. Надзвичайної точності та гнучкості голосу потребує аріозо «А хто мою голівоньку...». Дуже чітко треба вимовляти кожне слово, бо це важливо для сприймання змісту твору. Коли співачка правильно виконує аріозо, люди у залі наче перестають дихати, все завмирає. «Коли публіку обманеш раз, два, вона вже більше ніколи тобі не повірить», - 
зауважувала Соломія Крушельницька [4, с. 176]. Тому щоразу, виходячи на сцену, треба повністю поринати в образ, відчувати його і серцем, і душею. «Спів - це щедре мистецтво, яке стоїть на службі у серця», - говорив видатний педагог із вокалу Едмонд Дювернуа своїй учениці Х. Даркле [6, с. 130].

Образ Матері в опері «Катерина» - це не той образ, який можна вивчити, заспівати і бути спокійною. Потрібно щоразу перед виступом повертатися до нього і вдосконалювати, дивлячись з іншого боку, і щоразу вкладати ще більшої щирості та правдивості почуттів, ще більше вдосконалювати поєднання звуку і слова. Правдивість образу в опері - дуже важливий момент. Ніде - ні у гніві, ні у сльозах - не треба видобувати із себе жодного театрального звуку, бо це буде неправда... «Не вірю» - скаже глядач! Образ Матері увесь зітканий із запитань до Андрія: «Це ти, Андрію?», «Що нового?» є першими фразами цього образу. Спокійно, майже безнадійно запитує Мати. Рівно, без напруги потрібно проспівувати кожну ноту, але в кінці кожної фрази остання нота начебто повисає у повітрі. У такий спосіб необхідно змусити глядача постійно стежити не тільки за музичної темою, що звучить, а ще й за другорядним планом акторки-співачки, і в цей спосіб готується слухач до напружених стосунків у сім’ї Катерини між батьком, матір'ю та донькою.

Мати у відчаї запитує Катерину: «Що весілля, доню моя? А де ж твоя пара? Де світилки з друженьками, старости, бояри?» - та на всі ці запитання у Матері вже є відповіді, бо Мати пройшла вже довгий шлях у цьому віці.

Музичний матеріал написаний у такій напрузі, як тятива луку. Голос повинен звучати із грудним наповненням на форте з відчаєм і напругою (в написанні задіяний перехідний регістр) із раптовим переходом на теплий тембр, на піано. На фразі: «Доню моя, доню моя, цвіту мій рожевий! Як ягідку, як пташечку, кохала, ростила, на лишенько... Доню моя, що ти наробила?», - треба віддати всю материнську любов, щоб усі слухачі у залі відчули не тільки горе Матері, а й безкінечну любов до рідної кровинки. I які слова б не звучали, другим планом треба донести до глядача всепрощаючу материнську любов. Це головне завдання виконавиці ролі Матері в опері Миколи Аркаса «Катерина».

Голос повинен звучати без напруги, виблискуючи різноманітними барвами теплого відтінку. Ці фрази - як спогад 
про маленьку дитинку Катрусю - слухняну, схожу на рожеву ягідку та на щебетливу пташечку: «Як ягідку, як пташечку, кохала, ростила, на лишенько... Доню моя, що ти наробила?». Знову питання повисає у повітрі. Бо немає відповіді... I кодою цього образу є вигук: «Бог з тобою!». До цієї фрази виконавицю ролі уміло підводить не тільки Микола Аркас гучними акордами в оркестрі, а й Тарас Шевченко: «Доню моя, Доню моя, Дитя моє любе! Іди від нас, Бог з тобою!» - напружені перехідні ноти фа - мі - ре другої октави, і все завершується нотами ля, соль другої октави, закінчується нотою сі бекар, яка чітко вказує, що нема спасіння. Тому цю ноту, дуже важливу, треба закцентувати та в жодному разі не передержувати, не думати про красиве виконання цієї останньої ноти, а зняти іiі у відчаї. Щоб здобути такого ефекту, згадує Галина Анатоліївна Поліванова, диригент Е.І. Дубаян і режисер О.С. Кедрова працювали з нею щодо кожної музикальної фрази, вони допомогли співачці «вистраждати» свою героїню та стати справжньою: «Вічний пошук, праця, безсонні ночі, і все знову спочатку» [7, с. 112]. Від майстерності виконання фінальної фрази Матері в кінці другої дії опери слухачі повинні здригнутися у відчаї від незворотності обставин, у яких опинилася Катруся, а разом із нею вся іiі родина.

Висновки. Опера Миколи Аркаса «Катерина» започаткувала оперну шевченкініану і стала першою українською ліричною народно-побутовою оперою. Вона стала першою оперою у практиці драматичного театру без розмовних діалогів, що спонукало до підвищення артистичного рівня виконавців. Образ Матері традиційно притаманний українській літературі та поезії, тому його можна розглядати як особливе тематичне явище, що має глибинні культурні корені. Український образ Матері є національним культурним символом, який не втратив свого високого значення від древніх часів і дотепер.

Виконання партії Матері в опері «Катерина» вимагає від співачки великої напруги голосового апарату, великої насиченості, барвистості звуку, додаткової концентрації енергії, виразної декламації в речитативах, поривності, темпераменту. Головною задачею виконавиці-вокалістки $є$ повноцінне художнє втілення сценічного образу. Створення образу й особливості виконання розкриті на прикладі власного виконання автора. 
Прем’єра опери Миколи Аркаса «Катерина» відбулася в Одесі у 1899 р. Друга постановка в Одеському театрі опери і балету відбулася у 1957 р., третю здійснили через 32 роки. 31989 р. «Катерина» постійно з'являється на сцені Одеської національної опери.

\section{СПИСОК ЛІТЕРАТУРИ}

1. Авраменко С.М. Опера М. Аркаса «Катерина» - твір національного музично-театрального мистецтва. Шануючи пам'ять патріота України: Документи і матеріали про життя та діяльність М.М. Аркаса. Миколаїв, 1997. С. 57-63.

2. Аркас Микола - гордість України. Кримська Світлиия. 2009. № 13 (27 березня).

3. Аркас Микола Миколайович: життя, творчість, діяльність. Миколаїв, 2002. 260 с.

4. Врублевська В. Соломія Крушельницька : роман-біографія. Київ : Молодь, 1979. 336 с.

5. Гегель Г.Ф. Эстетика : в 4 т. Т. 1. Москва : Искусство, 1968. $312 \mathrm{c}$.

6. Джорже Сбырча. Первые шаги к славе. Бухарест : Ион крянгэ, 1982. $151 \mathrm{c.}$

7. Джулай А., Самусев Г. Галина Поливанова: гранд-интервью (страницы жизни и традиции одесской вокальной школы). Симферополь : Свиточ, 2011. $136 \mathrm{c.}$

8. Іванов В.Ф. Музичні джерела опери М. Аркаса «Катерина». Шануючи пам'ять патріота України. Документи $i$ матеріали про життя та діяльність М.М. Аркаса. Миколаїв, 1997. С. 47-51.

9. Корній Л.П. Історія української музики : підручник. Ч. 2. Друга половина XVIII ст. Київ - Харків - Нью-Йорк : Видавництво М.П. Коць, 1998. 387 с.

10. Николаев А.И. Основы литературоведения : учебное пособие. Иваново : ЛИСТОС, 2011. 255 с.

11. Опера «Катерина» в Москві. Українська Драматургія й театр від найдавніших часів до початку XX ст. Симон Васильович Петлюра. Офіційний сайт. URL: http://petlura.poltava.ua/.

12. «Катерина». URL: https://opera.odessa.ua/ua/repertuar/operi/ katerina.html.

13. Роднянская И. Образ художественный. Краткая литературная энциклопедия : в 6 т. Т. 5. Москва : Советская энциклопедия, 1968. C. $363-369$.

14. Хализеев В.Е. Теория литературы : учебник. Москва : Высшая школа, 2005. 405 c.

15. Шевченко Т.Г. Зібрання творів : у 6 т. Т. 1: Поезія 1837-1847 pp. Київ : Наукова думка, 2003. 784 с.

16. Шевченко Т.Г. Кобзар. Харків : Школа, 2009. 351 с. 


\section{REFERENCES}

1. Avramenko, S.M. (1997). Arkas's opera "Katerina" is a work of national musical and theatrical art. Honoring the memory of the patriot of Ukraine: Documents and materials about the life and work of M. Arkas. Mykolaiv [in Ukrainian].

2. Mykola Arkas is the pride of Ukraine. Crimean Svitlicya. 2009. № 13 (March 27) [in Ukrainian].

3. Arkas Mykola Mykolayovych: life, creativity, activity (2002). Mykolaiv [in Ukrainian].

4. Vrublevska, V. (1979). Solomiya Krushelnytska: novel-biography. Kyiv: Youth [in Ukrainian].

5. Hegel, G.F. (1968). Aesthetics: In 4 vols. Vol. 1. Moscow: Art [in Russian].

6. George, Sbyrcha (1982). First steps to glory. Bucharest: Ion Creangă [in Russian].

7. Dzhulay, A., Samusev, G. (2011). Galina Polivanova: grand interview (pages of the life and tradition of the Odessa vocal school). Simferopol: Svitoch [in Russian].

8. Ivanov, V.F. (1997). Musical sources of M. Arkas's opera "Katerina”. Honoring the memory of the patriot of Ukraine. Documents and materials about the life and work of M. Arkas. Mykolaiv [in Ukrainian].

9. Korniy, L.P. (1998). History of Ukrainian music: a textbook for musicians. universities. Part 2. The second half of the XVIII century. Kyiv - Kharkiv - New York: M.P. Kots Publishing House [in Ukrainian].

10. Nikolaev, A.I. (2011). Fundamentals of literary criticism: a textbook for students of philological specialties. Ivanovo: LISTOS [in Russian].

11. Opera "Catherine" in Moscow. Ukrainian Drama and Theater from ancient times to the beginning of the twentieth century. Simon Vasilyevich Petliura. Official site. URL: http://petlura.poltava.ua/ [in Ukrainian].

12. "Catherine". URL: https://opera.odessa.ua/ua/repertuar/operi/ katerina.html [in Ukrainian].

13. Rodnyanskaya, I. (1968). An artistic image. Brief literary encyclopedia: In 6 volumes. Vol. 5. Moscow: Soviet Encyclopedia [in Russian].

14. Khalizeev, V.E. (2005). Literature theory: textbook. Moscow: Higher School [in Russian].

15. Shevchenko, T.G. (2003). Collection of works: In 6 vols. Vol. 1: Poetry 1837-1847. Kyiv: Naukova Dumka [in Ukrainian].

16. Shevchenko, T.G. (2009). Kobzar. Kharkiv: School [in Ukrainian]. 